\title{
Wybrane płaszczyzny sporu o samorząd terytorialny w początkach III Rzeczpospolitej
}

PAWEŁ GOFRON - absolwent studiów doktoranckich na Wydziale Historii i Dziedzictwa Kulturowego Uniwersytetu Papieskiego Jana Pawła II w Krakowie; w niedalekiej przyszłości planowana obrona rozprawy doktorskiej w temacie relacji wojewodów krakowskich z samorządem miasta Krakowa w latach I990-I998. 
Spory o Rzeczpospolita. Przeglad wybranych dyskusji politycznych $i$ ustrojowych w ostatnim stuleciu, red. P. Gofron, A. Matuła, A. Paderewska, Kraków 2020, s. 86-103. DOI: http://dx.doi.org/10.15633/9788374388061.06

$\mathrm{J}$ ednym z elementów transformacji systemowej w Polsce, zapoczątkowanej w 1989 roku, był proces reaktywowania samorządu terytorialnego. W opiniach architektów ustroju samorządowego rodzącej się III Rzeczpospolitej dostrzec można - co nie powinno zresztą zaskakiwać - silne przekonanie, że reforma, którą zainicjowali i wdrażali, miała doniosłe znaczenie w tworzeniu podstaw demokratycznego państwa. Tak bowiem sądził Jerzy Regulski. Michał Kulesza stwierdził natomiast, że przywrócenie samorządu terytorialnego w 1990 roku pozwoliło przełamać trzy główne monopole państwa totalitarnego: monopol polityczny jednej i jedynej partii, zasadę jednolitej władzy państwowej oraz zasadę jednolitego funduszu własności państwowej². Podobne przekonanie - o doniosłości reformy samorządowej - podzielali również niektórzy teoretycy prawa i badacze polskiego ustroju. Paweł Sarnecki uznał bowiem restytucję samorządności za jedną z lepiej przeprowadzonych reform w ramach „popeerelowskich” przekształceń społeczno-prawno-ustrojowych ${ }^{3}$.

I J. Regulski, Samorzad III Rzeczypospolitej. Koncepcje i realizacja, Warszawa 200o, s. 7.

2 M. Kulesza, Transformacja ustroju administracyjnego Polski (I99o-200o), "Studia Iuridica” 38 (2000), s. 80.

3 P. Sarnecki, Samorzad terytorialny. Zasady ustrojowe i praktyka, Warszawa 2005 , s. 5 . 


\section{Znaczenie reformy samorządowej}

Wydaje się, że tym, co wyróżniało reformę samorządową, spośród przemian dokonujących w omawianym czasie na pozostałych płaszczyznach, było stosunkowo szybkie tempo jej przygotowania i dodatkowo względna sprawność implementacji. Stało się to możliwe za sprawą zainicjowanych na początku lat 8o. XX wieku solidnych przygotowań merytorycznych. Należy jednak mieć świadomość, że w okresie tzw. karnawału „Solidarności” sam ruch nie przywiązywał oficjalnie zbyt dużej wagi do kwestii samorządności. Pojawiające się w tym zakresie ewentualne postulaty dotyczyły bardziej aspektu zawodowo-pracowniczego niż terytorialnego, a same idee nie były zakotwiczone w głębszych przesłankach ${ }^{4}$. Z tego więc względu niejako na marginesie powstawały kolejne zespoły do spraw reaktywowania samorządu terytorialnego, spośród których dwa odegrały szczególną rolęs.

Pierwszy z nich - Zespół Samorządów Terytorialnych i Instrumentów Polityki Przestrzennej przy Społecznym Komitecie Reformy Gospodarczej, kierowany przez wspomnianego już Jerzego Regulskiego, przygotował fundamentalne opracowanie pt. Podstawowe zatożenia reformy samorzadu terytorialnego $w$ Polsce. W dokumencie tym, datowanym na 2 września 198I roku, zaznaczono, że w systemie zarządzania

4 J. Regulski, Samorząd III Rzeczypospolitej..., dz. cyt., s. 35n. Podczas I Krajowego Zjazdu Delegatów Niezależnego Samorządnego Związku Zawodowego „Solidarność", który odbywał się we wrześniu I98 I roku w Gdańsku, podjęto uchwałę programową zatytułowaną Samorządna Rzeczpospolita. Zasadnicze tezy dotyczące samorządu odnosiły się jednak w głównej mierze do spraw pracowniczych. Zagadnienie samorządu terytorialnego poruszone zostało dopiero w 22 punkcie wspomnianego dokumentu, http://www.solidarnosc. org.pl/I-kzd-I 98 I/item/6 I 28-uchwala-programowa-i-krajowego-zjazdu-delegatow (8.11.2019).

5 A. Barczewska-Dziobek, J. Dziobek-Romański, Rozwój i przemiany samorzadu terytorialnego po 1989 roku, w: Samorzad terytorialny w Polsce. Ksztattowanie się i ustrój obecny, red. J. Dziobek-Romański, Sandomierz 20I2, s. 72 n. 
państwem wyróżnić należy trzy podstawowe ogniwa reprezentujące poszczególnie rodzaje interesów: centrum, przedsiębiorstwa i społeczność lokalną. Jak dalej stwierdzono, instytucjonalne formy tych trzech ogniw stanowić miały odpowiednio: administracja rządowa, administracja gospodarcza przedsiębiorstw i ich zrzeszeń oraz samorząd terytorialny różnych szczebli' ${ }^{6}$.

$\mathrm{Na}$ czele drugiego z rzeczonych zespołów stanął wspomniany również Michał Kulesza. Efektem podjętych wokół jego osoby prac stał się pierwszy znaczący projekt ustawy o samorządzie terytorialnym i ordynacji wyborczej

$\mathrm{Na}$ ówczesnym etapie, chociaż myślano bardziej o naprawie państwa polskiego aniżeli całkowitej jego przebudowie, dało się zauważyć rozkwit różnych koncepcji co do tego, jak miał być ukształtowany odrodzony samorząd. Stan wojenny sprawił, że tego rodzaju wizje przybrały postać jedynie teoretycznych rozważań snutych w ramach badań naukowych, które to na dodatek prowadzono na wpół oficjalnie ${ }^{8}$. W takich oto obiektywnie trudnych okolicznościach w debatę o samorządzie zaangażował się również Kościół katolicki, który w 1983 roku w ramach Konferencji Episkopatu Polski spisał sygnowane przez Prymasa Polski Józefa Glempa dziesięciostronicowe postulaty dotyczące kierunków działań dla odtworzenia samorządności terytorialnej w Polsce?.

6 Z posiedzenia Spotecznego Zespotu Samorządów Terytorialnych i Instrumentów Polityki Przestrzennej pod przewodnictwem prof. Jerzego Regulskiego (2 września I98I r.), w: Reforma samorządowa. Materiaty źródtowe I980-I990, wyb. J. Regulski, Warszawa 2000, s. 57n.

7 A. Barczewska-Dziobek, J. Dziobek-Romański, Rozwój i przemiany samorządu terytorialnego po I989 roku, dz. cyt., s. 73.

8 J. Regulski, Samorząd III Rzeczypospolitej..., dz. cyt., s. 39.

9 List Episkopatu Polski w sprawie projektu ustawy o radach narodowych i samorzadzie terytorialnym, w: Reforma samorzadowa..., dz. cyt., s. I 2 I-I 3 I. W dokumencie tym zapisano m.in.: „System władz terenowych wymaga głębokiej reformy. Obecny stan - owoc ustawy z roku I950 - opiera się na obowiązującej wówczas stalinowskiej koncepcji państwa budującego podstawy socjalizmu. (...) Przeszło trzydziestoletnie funkcjonowanie obecnego 


\section{Dyskusje o wizji samorządności w okresie przełomu}

Powstałe w tym czasie liczne opracowania i dokumenty studialne zostały wykorzystane - jak pokazało późniejsze doświadczenie - w trakcie obrad „Okrąłego Stołu”, gdzie sprawa realnej reaktywacji samorządu stała się przedmiotem dyskursu, jakkolwiek jednak drugorzędnym, a nawet wręcz marginalnym. Analiza przebiegu debat podjętych w ciągu całej dekady, a przede wszystkim w końcówce lat 80. pozwala na wyróżnienie kilku głównych zagadnień, w obrębie których dokonywała się wymiana myśli. Pojawiały się bowiem zasadnicze pytania o istotę i formę samorządności. Zastanawiano się, czy miała ona przybrać postać iście społeczną i antypolityczną (a tym samym pozainstytucjonalna), czy raczej miała w sposób ściśle niezależny realizować się w ramach specjalnie przygotowanych do tego struktur władzy publicznej ${ }^{\mathrm{I}}$.

Warto w tym miejscu poczynić uwagę ogólną. Tytułowe płaszczyzny sporu o samorząd w obrębie środowisk proreformatorskich nie przybrały negatywnego charakteru. Było to spowodowane przede wszystkim tym, że u ich podstaw, tj. w zakresie kolejnych koncepcji rysowały się co prawda zależności konkurencyjne, ale nie antagonistyczne. Poprzez usamorządowienie miast i gmin, niezależnie od postulowanych form i kształtów tego rodzaju procesu i proponowanych wariantów docelowego modelu, wyznaczono sobie w tym względzie wspólny cel. Jego istotą było definitywne odejście od dotychczasowego systemu rad narodowych, będącego kwintesencją zasady jednolitej władzy państwowej i centralizmu - pozornie - demokratycznego ${ }^{\text {II }}$.

systemu władz terenowych udowodniło w sposób niepodlegający dyskusji, że jest on gospodarczo nieefektywny i nie tworzy fundamentów porozumienia narodowego" .

Io J. Regulski, Samorząd III Rzeczypospolitej..., dz. cyt., s. 38.

I I Bezpośrednio po uchwaleniu 8 marca 1990 roku ustawy o samorządzie gminnym (Dz. U. z I 990 r., nr I6, poz. 95) Michał Kulesza pisał o tej sprawie we „Wspólnocie”: „W przeciwieństwie do rad narodowych, które są terenowymi organami jednolitej władzy państwowej, rady gmin będą 
Jak pokazała historia, nie było to jednak prostym zadaniem. Swiwedczy o tym przebieg negocjacji w podjętych w ramach "Okrąłego Stołu” i obrazujący skalę problemu protokół rozbieżności podpisany w ramach - co znamienne - ledwie tzw. podstolika, a oficjalnie Podzespołu do Spraw Stowarzyszeń (sic!) i Samorządu Terytorialnego ${ }^{12}$. Kluczową kwestią sporną pozostawał charakter organów wykonawczych i przedstawicielskich władz lokalnych. Jak relacjonował uczestnik negocjacji Jerzy Regulski, ośrodek komunistyczny przekonywał, że mogły one obok funkcji samorządowych realizować również zadania administracji państwowej, pozostając równocześnie jej zintegrowaną częścią. Strona solidarnościowa nie zgadzała się na tego rodzaju rozwiązania, przypominając, że celem proponowanej w tym zakresie reformy jest przywrócenie samorządu terytorialnego w możliwie najczystszej postaci, a więc ze swoimi integralnymi organami działającymi w zakresie prawa, ale w pełni niezależnymi od administracji rządowej ${ }^{\mathrm{i} 3}$.

Wyliczając zagadnienia, które stały się u schyłku PRL-u przedmiotem debat o restytucji samorządności, nie sposób nie wspomnieć również o rozbieżnych stanowiskach co do wizji samorządu wojewódzkiego. Opozycja uważała, że choć tego rodzaju idea jest nader słuszna, to jednak traktować ją należało w kategoriach zobowiązań na przyszłość. Jak zgodnie przekonywano, ówczesne okoliczności nie sprzyjały bowiem rozszerzaniu reformy poza szczebel gminny. Peerelowska strona rządowa zabiegała natomiast o hybrydowe rozwiązanie, zgodnie z którym wojewoda miał z jednej strony stać na czele województwa

ciałami stanowiącymi i kontrolnymi samorządu terytorialnego. Ulega w ten sposób rozerwaniu monolityczny system zarządzania państwowego. "Gmina» przestaje być tylko określeniem jednostki terytorialnej, czyli pewnego obszaru, na którym działa organ państwowy. "Gmina» staje się określeniem wspólnoty samorządowej - związku mieszkańców tego terenu (korporacji)”. Zob. M. Kulesza, Budowanie samorządu, Warszawa 2008, s. I 5.

I 2 P. Olszewski, Problem samorządu terytorialnego w obradach „Okragtego Stotu”, „Polityka i Społeczeństwo” 4 (2007), s. 94-IO2.

I 3 J. Regulski, Samorząd III Rzeczypospolitej..., dz. cyt., s. 58n. 
posiadającego osobowość prawną, a z drugiej - pozostając urzędnikiem państwowym - wykonywać zadania zlecane przez rząd ${ }^{14}$.

Przeprowadzenie w czerwcu 1989 roku pierwszych po drugiej wojnie światowej częściowo wolnych wyborów sprawiło, że pomimo zrozumiałego oporu strony rządowej, szanse zrealizowania postulatów środowiska "prosamorządowego" zyskiwały coraz większe szanse na realizację. Okazało się, że wybrany w pełni demokratycznie Senat stał się jedynym rozsądnym miejscem dla zainicjowania tego rodzaju reformy. W tym celu powołano więc komisję samorządową, na czele której stanął senator Jerzy Regulski, a w jej składzie znaleźli się ponadto Jerzy Stępień, Zbigniew Rokicki i inni senatorowie, których wspierał m.in. poseł Walerian Pańko oraz profesorowie Zygmunt Niewiadomski, Tomasz Dybowski i Teresa Rabska. W niemal błyskawicznym tempie, bo już 29 lipca 1989 roku podczas pierwszego posiedzenia izba wyższa przyjęła Założenia ustroju prawnego samorządu terytorialnego, by następnie zainicjować prace legislacyjne nad projektem ustawy samorządowej ${ }^{15}$.

Okazję do zaangażowania w reformę samorządową dodatkowego, poza Senatem, ośrodka władzy stanowiła decyzja premiera Tadeusza Mazowieckiego o powołaniu Jerzego Regulskiego na funkcję pełnomocnika rządu ds. reformy samorządowej w randze podsekretarza stanu $^{16}$. W opracowanej dla Prezesa Rady Ministrów notatce nowo

I 4 J. Regulski, Ustrój samorządów w postulatach I989 roku, w: 25 lat odrodzonego samorządu w Polsce - osiagnięcia, porażki i zadania na przysztość, Warszawa 2014 , s. 6.

I 5 A. Barczewska-Dziobek, J. Dziobek-Romański, Rozwój i przemiany samorządu terytorialnego po I989 roku, dz. cyt., s. 74; J. Stępień, Ksztatt reaktywowanego samorządu terytorialnego $w$ zamierzeniu jego twórców, w: 25 lat odrodzonego samorządu w Polsce..., dz. cyt., s. I 2.

I6 J. Regulski, Samorząd III Rzeczypospolitej..., dz. cyt., s. 7I. W tym miejscu warto przybliżyć scenę, jaka według relacji Regulskiego miała miejsce podczas wręczania mu nominacji na funkcję pełnomocnika. Premier Mazowiecki miał mu wtedy powiedzieć: „Domaga się Pan samorządu w Polsce? To proszę go zbudować”. 
mianowany urzędnik wskazał, że reforma samorządowa to duże wyzwanie z tego przede wszystkim powodu, że będzie wymagać podjęcia zsynchronizowanych działań na trzech obszarach: legislacyjnym, społecznym, instytucjonalnym ${ }^{17}$.

\section{Harmonogram wdrażania reformy}

Spośród zarysowujących się w tym okresie tytułowych płaszczyzn sporu o samorząd jedna kwestia miała dość duże znaczenie. Obok szczegółowych założeń ustrojowych do uzgodnienia pozostawał bowiem jeszcze jeden ważki, choć wydawałoby się techniczny element projektowanej reformy - podstawowy harmonogram działań. W tym względzie główna oś sporu podzieliła środowiska reformatorskie i politycznych decydentów na trzy obozy. Zasadniczy problem sprowadzał się bowiem do wyboru jednego z trzech proponowanych rozwiązań. Wydaje się, że warto - za Regulskim, bezpośrednim uczestnikiem negocjacji - pokrótce przybliżyć te możliwości ${ }^{18}$.

Zgodnie z pierwszą opcją można było jesienią 1989 roku w pierwszej kolejności przeprowadzić przyspieszone wybory do rad narodowych i zmienić ich skład personalny. Dzięki temu doszłoby do w miarę sprawnej wymiany dotychczasowych członków obsadzonych w radach (niespełna półtora roku wcześniej) w wyniku wyborów dalekich jeszcze od demokratycznych ideałów. Należało jednak mieć świadomość, że rozwiązanie takie niosłoby za sobą konieczność odłożenia w czasie reform o charakterze ustrojowym. To z kolei oznaczało, że na nic by się mogło zdać personalne odświeżenie rad narodowych przy jednoczesnym utrzymaniu dotychczasowego ich modelu, silnie ograniczającego samodzielność, niezależność i możliwość podejmowania realnych

I7 Notatka prof. Jerzego Regulskiego dla premiera Tadeusza Mazowieckiego, w: Reforma samorzadowa..., dz. cyt., s. 223.

I 8 J. Regulski, Samorząd III Rzeczypospolitej..., dz. cyt., s. 76n. 
decyzji. Wydawało się więc, że to rozwiązanie nie będzie współgrało, a wręcz może się kłócić z podstawowym założeniem reformy samorządowej, czyli aktywizacją społeczności lokalnych ${ }^{19}$.

Druga propozycja była zgoła odmienna. Priorytetem miało być solidne opracowanie projektów prawa samorządowego, a następnie dokonanie kompleksowych nowelizacji. Szacowano, że ten złożony proces mógłby zająć co najmniej półtora roku. Oznaczało to, że władze lokalne funkcjonowałyby na dotychczasowych, peerelowskich zasadach, a wybory samorządowe - w tej propozycji niejako drugoplanowe mogłyby się odbyć na gruncie w pełni usystematyzowanego ustroju dopiero w I99I roku. Pojawiało się jednak pytanie, czy jest to opcja zasadna w obliczu silnej presji społecznej i dobitnie artykułowanych żądań usunięcia dotychczasowej administracji ${ }^{20}$.

W debacie nad kształtem harmonogramu reformy samorządowej zarysowała się również trzecia koncepcja, będąca poniekąd zlepkiem dwóch poprzednich. Jej istotą było niezwłoczne dokonanie najważniejszych zmian w prawie o charakterze ustrojowym i równie szybkie zorganizowanie i przeprowadzenie wyborów samorządowych w zupełnie nowej jakości. Później natomiast, sukcesywnie miały być wprowadzane kolejne zmiany obrazujące bardziej szczegółowe założenia, uzgodnione już w nowych realiach ustrojowych. Za wyborem tego rozwiązania przemawiać miał fakt, że projekty zasadniczych zmian ustrojowych w obrębie samorządu terytorialnego były już w dużej mierze przygotowane ${ }^{21}$.

Uwzględniwszy wady i zalety każdej z tych propozycji, ośrodek reformatorski zdecydował, że najkorzystniejsza w ówczesnych warunkach będzie propozycja trzecia i to według niej ostatecznie skonstruowano harmonogram. 29 grudnia 1989 roku uchwalono nowelę Konstytucji PRL, w której oprócz zmiany nazwy państwa i przyjęcia fundamental-

\footnotetext{
I9 J. Regulski, Samorząd III Rzeczypospolitej..., dz. cyt., s. 76n..

20 J. Regulski, Samorząd III Rzeczypospolitej..., dz. cyt., s. 76n.

2 I J. Regulski, Samorząd III Rzeczypospolitej..., dz. cyt., s. 76n.
} 
nej zasady demokratycznego państwa prawa zagwarantowano udział samorządu terytorialnego w sprawowaniu władzy ${ }^{22}$. Z kolei 8 marca I990 roku dokonano kolejnej nowelizacji ustawy zasadniczej, w obrębie której samorządowi poświęcono cały rozdział ${ }^{23}$. W tym samym dniu przyjęte zostały również ustawy restytuujące samorząd terytorialny, na mocy których ostatecznie zlikwidowany został system rad narodowych, a wprowadzony model rady gminy z zarządem i wójtem, burmistrzem lub prezydentem jako organem wykonawczym ${ }^{24}$. Następnie Io maja I990 roku uchwalono przepisy wprowadzające ustawę o samorządzie terytorialnym ${ }^{25}$. Kilkanaście dni później, 27 maja 1990 roku, odbyły się natomiast wybory samorządowe ${ }^{26}$.

W kontekście przytoczonych aktów prawnych tworzących zręby nowego ustroju państwa z uwzględnieniem samorządu terytorialnego jako jednego z jego elementów warto wspomnieć jeszcze o tzw. ustawie kompetencyjnej z I7 maja I990 roku²7. Uzgodnienie jej zapisów stanowiło bowiem kolejną płaszczyznę wymiany myśli w zakresie wizji samorządu terytorialnego. Celem rzeczonego aktu prawnego było

22 Ustawa z dnia 29 grudnia 1989 roku o zmianie Konstytucji Polskiej Rzeczypospolitej Ludowej (Dz. U. z I989 Nr 75, poz. 444).

23 Ustawa z dnia 8 marca 1990 roku o zmianie Konstytucji Rzeczypospolitej Polskiej (Dz. U. z I 990 Nr I6, poz. 94).

24 Ustawa z dnia 8 marca I990 roku o samorządzie terytorialnym (Dz. U. z I990 Nr I6, poz. 95); Ustawa z dnia 8 marca I990 roku. Ordynacja wyborcza do rad gmin (Dz. U. z I990 Nr I6, poz. 96).

25 Ustawa z dnia ro maja I990 roku. Przepisy wprowadzające ustawę o samorządzie terytorialnym i ustawę o pracownikach samorządowych (Dz. U. z I990 Nr 32, poz. I9I).

26 Zarządzenie Prezesa Rady Ministrów z dnia I 9 marca I 990 roku w sprawie zarządzenia wyborów do rad gmin (Dz. U. z I $990 \mathrm{Nr}$ I7, poz. I o I). Szerzej o wyborach samorządowych w 1990 roku, w: A. K. Piasecki, Wybory w Polsce I989-20II, Kraków 2012, s. 24-32.

27 Ustawa z dnia I 7 maja I 990 roku o podziale zadań i kompetencji określonych w ustawach szczególnych pomiędzy organy gminy a organy administracji rządowej oraz o zmianie niektórych ustaw (Dz. U. z I $990 \mathrm{Nr}$ 34, poz. Io I). 
uporządkowanie zadań i kompetencji właściwych dla władz lokalnych poprzez ich klarowne rozdzielenie między terytorialną administrację rządową a ośrodek samorządowy. Jak można się domyślić, pierwsza strona nie była zbytnio skłonna oddać przynależnych jej uprawnień, druga natomiast chciała zyskać możliwość sprawowania realnej władzy publicznej. Podjęta na ten temat debata okazała się jednak na tyle konstruktywna, że poziom decentralizacji okazał się względnie satysfakcjonujący dla obu stron ${ }^{28}$.

\section{Spór o powiaty}

Z katalogu wybranych sporów o samorząd terytorialny warto przytoczyć jeszcze jeden, który zarysował się nie tyle w pierwotnej fazie budowania i konstruowania, lecz na późniejszym etapie kształtowania i rozwijania. Jak zostało już wspomniane, po wprowadzeniu samorządu gminnego w środowisku proreformatorskim wyraźnie stwierdzano, że choć na miarę ówczesnych okoliczności było to rozwiązanie możliwie najlepsze, to miało ono bardziej wytyczać kierunek dalszych reform, aniżeli stanowić ich docelową i ostateczną wersję. Z biegiem czasu powstawały więc kolejne dokumenty studialne opisujące wizje rozwoju odrodzonej samorządności.

W październiku 1992 roku zebrał je Michał Kulesza, nowo mianowany przez premier Hannę Suchocką podsekretarz stanu w Urzędzie Rady Ministrów i pełnomocnik rządu ds. reformy administracji publicznej. Jego celem stało się odtąd kompleksowe przygotowanie i zrealizowanie tzw. drugiego etapu reformy samorządowo-administracyjnej, czyli rozbudowanie samorządu terytorialnego poza szczebel gminny, przy jednoczesnej dalszej decentralizacji terenowej administracji rządowej ${ }^{29}$.

28 J. Regulski, Samorzad III Rzeczypospolitej..., dz. cyt., s. 83.

29 M. Kulesza, Stan prac nad reforma administracji publicznej, „Samorząd Terytorialny" 3 (I993) nr Iо (34), s. 42-47. 
Mając na uwadze tak wytyczony kierunek działań, podjęto decyzję o wprowadzeniu powiatów, które miały nie być celem samym w sobie, lecz instrumentem napędowym dla reformy całego państwa. W prowadzenie powiatów zaplanowano pierwotnie na I stycznia I995 roku, niemniej jednak na roczny okres poprzedzający jej wprowadzenie przygotowano bezprecedensowy program pilotażowy, nazwany wprost „eksperymentalnym rozwiązaniem”. Projekt ten skierowany był do 46 dużych miast, które miały w przyszłości samodzielnie realizować zadania powiatu. W ramach pilotażu miały one przejąć nowe kompetencje $\mathrm{w}$ istocie im właściwe wraz z niezbędną do ich wykonywania infrastrukturą i odpowiednimi środkami finansowymi. Proces ten miał być usankcjonowany poprzez dwustronne porozumienie podpisane przez właściwego prezydenta miasta i odpowiedniego wojewodę ${ }^{30}$.

Program pilotażowy zainicjowano w lipcu 1993 roku za rządu Hanny Suchockiej. Władze samorządowe miast przystąpiły odtąd do negocjacji, a następnie sygnowania stosownych porozumieńn ${ }^{31}$. Niemniej jednak 26 października 1993 roku realizacja programu została zawieszona. Decyzję taką podjął w pierwszym dniu swojego urzędowania premier Waldemar Pawlak ${ }^{32}$, który stanął na czele koalicyjnego rządu

30 M. Kulesza, Miejski program pilotażowy administracji publicznej (omówienie ogólne), „Samorząd Terytorialny” 5 (1995) nr I 2 (60), s. 7 I-78.

3 I Podstawę prawną całego przedsięwzięcia stanowił art. 35 ustawy budżetowej na rok 1993 z dnia I 2 lutego 1993 roku (Dz. U. z I 993 r., nr I 4, poz. 63), a także - zapowiedziane uprzednio przez wyżej wskazany zapis - rozporządzenie Rady Ministrów z dnia I 3 lipca 1993 roku w sprawie określenia zadań i kompetencji z zakresu rządowej administracji ogólnej i specjalnej, które mogą być przekazane niektórym gminom o statusie miasta, wraz z mieniem służącym do ich wykonywania, a także zasad i trybu przekazania (Dz. U. z I993 r., nr 65, poz. 309).

32 Archiwum Zakładowe Małopolskiego Urzędu Wojewódzkiego w Krakowie, Urząd Wojewódzki w Krakowie 1990-1998, spis 45/I/24, t. 5, pismo dyrektora generalnego Urzędu Rady Ministrów Mirosława Steca do wojewodów uczestniczących w programie pilotażowym $\mathrm{w}$ sprawie wstrzymania podpisywania porozumień pilotażowych. 
SLD-PSL uformowanego wskutek wyniku wyborów parlamentarnych z I9 września 1993 roku $^{33}$.

Co więcej, w drugim dniu premierostwa Pawlaka, kierowana przez niego Rada Ministrów przyjęła nowelizację rozporządzenia pilotażowego będącego podstawą prawną całego programu. W dokumencie tym określono, że zawieranie dotychczasowych porozumień zawiesza się do 30 listopada 1993 roku, a podpisywanie umów między wojewodami a prezydentami miast będzie się odbywać na nowych zasadach ${ }^{34}$. 30 listopada 1993 roku rząd Pawlaka przyjął kolejne rozporządzenie nowelizujące podstawy prawne pilotażu. Zasadniczą zmianę dokonaną w tym dokumencie stanowiło niemal pięciokrotne zwiększenie liczby instytucji wyłączonych a priori z możliwości przekazania ich prowadzenia władzom samorządowym. Decyzją rządu zmniejszono również środki na realizację programu pilotażowego - z przeszło I4 bilionów starych złotych do 8 bilionów ${ }^{35}$.

Nie powinno dziwić, że do tego rodzaju zmian krytycznie odnosił się ośrodek prosamorządowy z Michałem Kuleszą, jako architektem pilotażu reformy powiatowej na czele ${ }^{36}$. Same również władze samorządowe

33 A. K. Piasecki, Wybory w Polsce I989-20II, dz. cyt., s. 6I-70.

34 Rozporządzenie Rady Ministrów z dnia 27 października I 993 roku zmieniające rozporządzenie w sprawie określenia zadań i kompetencji z zakresu rządowej administracji ogólnej i specjalnej, które mogą być przekazane niektórym gminom o statusie miasta, wraz z mieniem służącym do ich wykonywania, a także zasad i trybu przekazania (Dz. U. z I993 $\mathrm{Nr}$ I03, poz. 47I).

35 Rozporządzenie Rady Ministrów z dnia 30 listopada 1993 roku zmieniające rozporządzenie w sprawie określenia zadań i kompetencji z zakresu rządowej administracji ogólnej i specjalnej, które mogą być przekazane niektórym gminom o statusie miasta, wraz z mieniem służącym do ich wykonywania, a także zasad i trybu przekazania (Dz. U. z I $993 \mathrm{Nr}$ I I 5, poz. 510); M. Kulesza, Miejski program pilotażowy..., dz. cyt., s. 75 n.

36 Wymownym tego znakiem było złożenie przez Michała Kuleszę i 6 V I995 roku rezygnacji z funkcji pełnomocnika rządu ds. reformy administracji publicznej. W liście do premiera Pawlaka napisał on: „Od czasu 
z wielkim żalem komentowały posunięcia rządu ${ }^{37}$. Ostatecznie program pilotażowy w mocno okrojonej formie został zrealizowany w I994 roku, a następnie kontynuowany w kolejnym roku, po czym ustąpił miejsca tzw. ustawie miejskiej, która weszła w życie I stycznia $1996 \mathrm{roku}^{38}$. Nie ulega wątpliwości, że decyzją władz państwowych pod koniec 1993 roku nastąpiło zahamowanie całościowej reformy, a - jak pokazała historia - na wprowadzenie powiatów trzeba było poczekać do 1999 roku.

\section{Zakończenie}

Zarysowanie wybranych spornych obszarów w debacie samorządowej w początkach III Rzeczpospolitej ograniczone zostało do kilku kluczowych kwestii, przede wszystkim o charakterze ustrojowym. Należy jednak mieć świadomość, że pojawiały się również inne, nieomówione w niniejszym artykule problemy, spośród których pokrótce wymienić można kwestię wpływu wojny na górze w obozie „Solidarności” na kształt reform samorządowych, a także spory o zasady finansowania gmin, zakres komunalizacji, kompetencje sejmików wojewódzkich, wizję rejonów administracyjnych w województwie, ogólnokrajową reprezentację gmin, czy wreszcie spór o drugi etap reformy i wizję samorządowych powiatów i województw.

objęcia przez Pana misji Prezesa Rady Ministrów sprawy reformy administracji publicznej (a wraz z nią - całej sfery usług publicznych) znalazły się w impasie" (M. Kulesza, Budowanie samorzadu..., dz. cyt., s. I62).

372 XII 1993 roku w „Dzienniku Polskim” ukazał się artykuł, w którym prezydent Krakowa Józef Lassota w następujący sposób skomentował decyzje rządu Waldemara Pawlaka: „Odnoszę wrażenie, że intencją nowej ekipy rządowej było całkowite utrącenie idei pilotażu, a teraz, wobec zdecydowanej postawy samorządów, następuje swoiste rozmiękczenie".

38 Ustawa z dnia 24 listopada 1995 roku o zmianie zakresu działania niektórych miast oraz o miejskich strefach usług publicznych (Dz. U. z I995 Nr I4I, poz. 692). 


\section{Streszczenie}

WYBRANE PŁASZCZYZNY SPORU O SAMORZĄD TERYTORIALNY W POCZĄTKACH III RZECZPOSPOLITEJ

Niniejszy artykuł prezentuje wybrane płaszczyzny sporu o samorząd terytorialny w Polsce w okresie transformacji ustrojowej - od schyłku PRL-u do początków III Rzeczpospolitej. We wstępie podkreślono znaczenie reformy samorządowej. W zasadniczej treści zrekonstruowano w zarysie dyskurs o samorządzie terytorialnym w obradach „Okrągłego Stołu”. Omówiono ponadto projekty harmonogramu wdrażania reformy. Ostatnia część tekstu dotyczy natomiast sporu o wprowadzenie powiatów jako drugiego szczebla samorządu.

\section{Summary}

SELECTED GROUNDS OF STRIFE OVER THE SELF-GOVERNMENT A T THE BEGINNING OF THE THIRD POLISH REPUBLIC

This article presents the selected grounds of strife over the self-government in Poland during the political transformation - from the end of the Polish People's Republic to the beginning of the Third Republic of Poland. In the introduction the importance of the self-government reform was emphasized. In the main content the discourse over the self-government during the Round Table Talks was reconstructed in outline. Moreover, the projects of the implementation scheme of the reform were discussed. The last part of the text concerns the dispute over the introduction of poviats as the second level of self-government.

\section{Bibliografia}

Archiwum Zakładowe Małopolskiego Urzędu Wojewódzkiego w Krakowie, Urząd Wojewódzki w Krakowie 1990-1998, spis 45/I/24, t. 5 , 
pismo dyrektora generalnego Urzędu Rady Ministrów Mirosława Steca do wojewodów uczestniczących w programie pilotażowym w sprawie wstrzymania podpisywania porozumień pilotażowych. Barczewska-Dziobek A., Dziobek-Romański J., Rozwój i przemiany samorzadu terytorialnego po 1989 roku, w: Samorzad terytorialny $w$ Polsce. Ksztattowanie się i ustrój obecny, red. J. Dziobek-Romański, Sandomierz 20I2, s. 72-II4.

Kulesza M., Budowanie samorzadu, Warszawa 2008.

Kulesza M., Miejski program pilotażowy administracji publicznej (omówienie ogólne), „Samorząd Terytorialny” 5 (1995) nr I2 (60), s. 7I-78.

Kulesza M., Stan prac nad reformą administracji publicznej, „Samorząd Terytorialny" 3 (1993) nr Io (34), s. 42-47.

Kulesza M., Transformacja ustroju administracyjnego Polski (I990-200o), "Studia Iuridica” 38 (2000), s. 79-86.

List Episkopatu Polski w sprawie projektu ustawy o radach narodowych i samorzadzie terytorialnym, w: Reforma samorzadowa. Materiaty źródtowe 1980-I990, wyb. J. Regulski, Warszawa 2000, s. I2I-I32.

Notatka prof. Jerzego Regulskiego dla premiera Tadeusza Mazowieckiego, w: Reforma samorządowa. Materiaty źródtowe 1980-1990, wyb. J. Regulski, Warszawa 2000, s. 223-226.

Olszewski P., Problem samorządu terytorialnego w obradach „Okragtego Stotu”, „Polityka i Społeczeństwo” 4 (2007), s. 94-IO2.

Piasecki A. K., Wybory w Polsce 1989-20II, Kraków 2012.

Regulski J., Samorząd III Rzeczypospolitej. Koncepcje i realizacja, Warszawa 2000.

Regulski J., Ustrój samorządów w postulatach I989 roku, w: 25 lat odrodzonego samorzadu $w$ Polsce - osiagnięcia, porażki i zadania na przysztość, Warszawa 20I4, s. 5-7.

Rozporządzenie Rady Ministrów z dnia I3 lipca I993 roku w sprawie określenia zadań i kompetencji z zakresu rządowej administracji ogólnej i specjalnej, które mogą być przekazane niektórym gminom o statusie miasta, wraz z mieniem służącym do ich wykonywania, a także zasad i trybu przekazania (Dz. U. z $1993 \mathrm{Nr} 65$, poz. 309). 
Rozporządzenie Rady Ministrów z dnia 27 października 1993 roku zmieniające rozporządzenie w sprawie określenia zadań i kompetencji z zakresu rządowej administracji ogólnej i specjalnej, które mogą być przekazane niektórym gminom o statusie miasta, wraz z mieniem służącym do ich wykonywania, a także zasad i trybu przekazania (Dz. U. z $1993 \mathrm{Nr}$ I03, poz. 47I).

Rozporządzenie Rady Ministrów z dnia 30 listopada 1993 roku zmieniające rozporządzenie w sprawie określenia zadań i kompetencji z zakresu rządowej administracji ogólnej i specjalnej, które mogą być przekazane niektórym gminom o statusie miasta, wraz z mieniem służącym do ich wykonywania, a także zasad i trybu przekazania (Dz. U. z $1993 \mathrm{Nr}$ II5, poz. 510).

Sarnecki P., Samorzad terytorialny. Zasady ustrojowe i praktyka, Warszawa 2005.

Stępień J., Ksztatt reaktywowanego samorządu terytorialnego $w$ zamierzeniu jego twórców, w: 25 lat odrodzonego samorzadu $w$ Polsceosiagnięcia, porażki i zadania na przysztość, Warszawa 20I4, s. II-I3.

Ustawa budżetowa na rok 1993 z dnia I2 lutego I993 roku (Dz.U. z $1993 \mathrm{Nr}$ I4, poz. 63).

Ustawa z dnia Io maja 1990 roku. Przepisy wprowadzające ustawę o samorządzie terytorialnym i ustawę o pracownikach samorządowych (Dz. U. z I990 Nr 32, poz. I9I).

Ustawa z dnia I7 maja I990 roku o podziale zadań i kompetencji określonych w ustawach szczególnych pomiędzy organy gminy a organy administracji rządowej oraz o zmianie niektórych ustaw (Dz. U. z I990 Nr 34, poz. IOI).

Ustawa z dnia 24 listopada 1995 roku o zmianie zakresu działania niektórych miast oraz o miejskich strefach usług publicznych (Dz. U. z I995 Nr I4I, poz. 692).

Ustawa z dnia 29 grudnia 1989 roku o zmianie Konstytucji Polskiej Rzeczypospolitej Ludowej (Dz. U. z I989 Nr 75, poz. 444).

Ustawa z dnia 8 marca 1990 roku o samorządzie terytorialnym (Dz. U. z I990 Nr I6, poz. 95). 
Ustawa z dnia 8 marca 1990 roku o zmianie Konstytucji Rzeczypospolitej Polskiej (Dz. U. z I990 Nr I6, poz. 94).

Ustawa z dnia 8 marca 1990 roku. Ordynacja wyborcza do rad gmin (Dz. U. z I990 Nr i6, poz. 96).

Z posiedzenia Spotecznego Zespotu Samorzadów Terytorialnych i Instrumentów Polityki Przestrzennej pod przewodnictwem prof. Jerzego Regulskiego (2 września I98I r.), w: Reforma samorządowa. Materiaty źródtowe 1980-1990, wyb. J. Regulski, Warszawa 2000, s. 57-76.

Zarządzenie Prezesa Rady Ministrów z dnia 19 marca 1990 roku w sprawie zarządzenia wyborów do rad gmin (Dz. U. z I990 Nr I7, poz. IOI). 